\title{
Youth Struggles: From the Arab Spring to Black Lives Matter \& Beyond
}

\section{Alcinda Manuel Honwana}

\begin{abstract}
The majority of young people in Africa are today living in 'waithood,' a prolonged, difficult, and dynamic transition into adult life. This experience is shared with an increasing number of young people in the developed North who are also grappling with issues of joblessness and political exclusion. This waithood generation is increasingly losing faith in the ability of its leaders to address young people's needs and expectations, and it is rebelling against the status quo. From the youth uprisings that led to the Arab Spring and the ousting of Abdoulaye Wade in Senegal and Campaore in Burkina Faso, to political protest movements such as Occupy Wall Street and Black Lives Matter in the US and Los Indignados in Spain, young people have been at the forefront of political change. However, they have not yet been able to effect systemic change. While profound social transformation takes time, this generation is still wrestling with how to move beyond street protest and have a lasting impact on politics and governance.
\end{abstract}

Résumée: La majorité des jeunes en Afrique vivent aujourd'hui dans une situation d'attente, que j'appelle waithood, une transition prolongée, difficile et dynamique vers la vie adulte. Cette expérience est partagée avec un nombre croissant de jeunes du Nord développé qui sont également aux prises avec les mêmes problèmes de chômage et d'exclusion politique. Cette génération perd de plus en plus confiance dans la capacité de ses dirigeants à répondre à leurs attentes et leurs besoins et elle se rebelle contre le statu quo. Des soulèvements de jeunes qui ont 
conduit au printemps arabe et l'éviction d'Abdoulaye Wade au Sénégal et de Campaore au Burkina Faso à des mouvements de protestation politique tels que Occupy Wall Street et Black Lives Matter aux États-Unis, et Los Indignados en Espagne, des jeunes ont été à l'avant-garde du changement politique. Cependant, ils n'ont pas été en mesure d'effectuer un changement systémique. Alors que la profonde transformation sociale prend du temps, cette génération est encore en train de se débattre sur la façon de dépasser la protestation de la rue et d'avoir un impact sur la politique et la gouvernance.

Abstrato: A maioria dos jovens em África vive hoje em "waithood", uma transição prolongada, difícil e dinâmica para a vida adulta. Esta experiência dos jovens Africanos é compartilhada com um número crescente de jovens no Norte Global que também enfrentam as mesmas questões de desemprego e exclusão política e social. Esta geração waithood perdeu fé na capacidade de seus líderes de atender às suas necessidades e aspirações e vem-se rebelando contra o status quo. Desde as revoltas de jovens que levaram à Primavera Árabe, à expulsão de Abdoulaye Wade no Senegal e de Compaoré em Burkina Faso, e aos movimentos de protesto político, como Occupy Wall Street e Black Lives Matter nos EUA, e Los Indignados na Espanha, os jovens têm estado na vanguarda da mudança política. No entanto, estes esforços não lhes permitiram efetuar mudanças sistêmicas. Enquanto as transformações sociais levam tempo, esta geração continua lutando e procurando formas de superar of os protestos de rua e ter um impacto na vida política e na governação.

Alcinda Manuel Honwana is a Centennial Professor at the London School of Economics and Political Science (LSE). She is also a visiting professor of Anthropology and International 
Development at the Open University, where she held the Chair in International Development and directed the International Development Centre. Honwana has been an Inter-regional Adviser on social development policy at the United Nations and a Program Director at the Social Science Research Council (SSRC) in New York. She taught anthropology at the New School of Social Research in New York and at the University of Cape Town. Alcinda Honwana has carried out extensive research on political conflict and politics of culture; on the impact of war on children and youth; as well as on youth politics, social movements, and political protest. Her latest books include Youth and Revolution in Tunisia (2013) and The Time of Youth: Work, Social Change and Politics in Africa (2012). a.m.honwana@open.ac.uk.

Key Words: Youth; transitions to adulthood; youth politics; collective mobilizations; civil rights social movements; social change

Come mothers and fathers

Throughout the land

And don't criticize

What you can't understand

Your sons and your daughters

Are beyond your command

Your old road is rapidly agin' [aging]

Please get out of the new one if you can't lend a hand

For the times, they are a-changin, ${ }^{\text {1 }}$ 
In 1963, these lyrics by Bob Dylan for The Times They Are a-Changin' foreshadowed the youth uprisings of 1968 in Europe. However, Dylan's generation appears to have lost its fight and to have been co-opted into the establishment. Half a century later, Europe and most of the world is witnessing a new wave of youth protests that stem from socioeconomic, political, and cultural grievances. This new wave of protests started in the African continent, when in early 2011 young Tunisians and Egyptians took to the streets and ousted two longstanding dictatorships. These events marked the beginning of a new era in youth political activism across the world. Street protests, riots, and demonstrations were carried out by youth in locations across the globe such as Senegal, Greece, South Africa, Chile, Hong Kong, Portugal, Burkina Faso, the UK, Brazil, and the US. Beyond the wide disparities in their material, cultural, and political situations, young people in rich and poor countries alike are affected by similar problems of exclusion and restricted futures. These worldwide uprisings need to be understood in the context of this generation's struggles for political, social, and economic emancipation.

I will develop three fundamental arguments: First, youth protest movements stem directly from the economic and social pressures the youth endure, and from their pervasive political marginalization. Young people in Africa are living in what I refer to as 'waithood,' a prolonged, difficult, and dynamic transition into adulthood. But waithood isn't just an African experience. Young people in the developed North also grapple with the same issues of joblessness and political exclusion. I will discuss waithood and the ways in which it is manifested in Africa as well as in the developed countries. Second, I argue that young people are rebelling against the status quo. They have been moving away from dispersed and unstructured social and political acts, and into more organized protests in the public arena. Central here is the loss of faith in the ability of politicians to deliver concrete responses to young people's needs and expectations. The 
realities of young women's and young men's daily lives expose the gap between the promise of equity, individual freedoms, and prosperity, and their lived experience of marginalization, exclusion, and lack of opportunities. Moreover, young people are increasingly aware of the complicity between global and local forces that leads to corrupt governments acting with impunity across the world. And third, youth political protest movements continue to impact social and political change, as seen in the fall of autocratic regimes and the reversal of unpopular government policy. More significantly, these movements have prompted a fundamental change in young peoples' mindsets, allowing them to believe that their actions matter and that they can make a difference. Nevertheless, they have not been able to effect systemic change. While profound transformation takes time, the questions young people are wrestling with include: how to move beyond street protest and play an active role in politics and governance; and how can this generation create a new kind of politics?

My analysis is based on in-depth interviews I conducted with young people in various African countries, which resulted in my two latest books, The Time of Youth: Work Social Change and Politics in Africa (2012) and Youth and Revolution in Tunisia (2013). It is also informed by my reading of youth struggles and youth social movements across the globe.

\section{Waithood}

In Africa, young people constitute a disenfranchised majority, living in waithood-a liminal space in which they are neither dependent children nor autonomous adults. They are largely excluded from major socioeconomic institutions and political processes. Whatever their class background, many youths have no secure jobs and cannot afford to setup their own households and establish families. The ability to work and provide for themselves, and for others, defines a 
person's self-worth and position in the family and in the community, and constitutes an important marker of adulthood. The experience of waithood among young people differs by class, gender, and level of education. Men face the pressures of getting a steady job, finding a home, and covering the costs of marriage and family building. Although women are becoming better educated and have always engaged in productive labor alongside household chores, marriage and motherhood are still important markers of adulthood. While giving birth may provide girls an entry into adulthood, their ability to attain full adult status often depends on men moving beyond waithood (Honwana 2012). Middle class youths, with stronger socioeconomic and political connections, may experience waithood differently.

In Mozambique, in the past, becoming a labor migrant in the South African mines constituted a rite of passage to adulthood. As exploitative as the South African mining sector might have been, these jobs helped young Mozambicans to become husbands, fathers, and providers for their families and, in turn, allowed young women to become wives, mothers, and homemakers. Similarly, getting a university degree guaranteed access to jobs and upward mobility for new graduates. Today, however, African societies do not offer reliable pathways to adulthood; jobs such as the ones in the mines are gone, and a university degree does not necessarily lead to reliable employment. Indeed, traditional ways of making this transition have broken down, and new ways of attaining adult status are yet to be developed (Honwana 2012).

However, the young are not merely waiting and hoping that their situation will change of its own accord. Waithood is propelling them to be be creative and improvise livelihoods outside of dominant economic and familial frameworks (Honwana \& De Boeck 2005). Henrietta Moore calls this "self-stylization, an obstinate search for a style of existence, [and] a way of being" (2011:2). The Internet and its social networks make this process easier. And young people's 
responses to waithood attest to this resourcefulness. Young people in waithood are indeed creating new dynamic sites for inventiveness and survival. From interviews with young people, in my book The Time of Youth (2012), Mozambicans use the Portuguese expression desenrascar a vida (to eke out a living); Senegalese and Tunisians use the French word débrouillage (making do); while South Africans say: 'we are just getting by.' The idea of desenrascar a vida, débrouillage or getting by situates the waithood experience in the realm of improvisation, or "making it up as you go along," and entails a conscious effort to assess challenges and possibilities, as well as plot scenarios conducive to the achievement of specific goals (Vigh 2009). These young people operate like Lévi-Strauss's bricoleur, a ‘jack-of-all-trades' who manipulates and takes advantage of circumstances whenever possible to attain his or her own ends (Lévi-Strauss, 1966). These young people's actions also function like Michel de Certeau's tactics, or daily struggles that respond to immediate needs rather than longer-term strategies designed to achieve broader ends (De Certeau 1984). Young Africans discover and invent new ways of existing in the margins.

This is the experience of many young men and women who engage in street vending, cross-border trading and smuggling; those who migrate illegally to South Africa or to Europe; and those who end up in criminal networks as swindlers, traffickers, and gangsters. Young women and men often see little option but to also use their sexuality as a means of gaining a livelihood. They engage in intimate, and often exploitative, relationships with wealthy and powerful men and women (commonly known as 'sugardaddies' and 'sugarmamas') for money, gifts, and access to fashionable goods. Some young people become successful entrepreneurs. Depending on their gender, they have taken up activities such as repairing electronic devices; making and marketing clothing and jewelry; and doing hair and nails. Others are creating new 
artistic, musical, and performance forms, making graffiti, painting murals, writing blogs, and becoming savvy Internet users. Unemployed and underemployed graduates are taking up jobs usually performed by less-educated youths. Kate Meagher's work shows that a shrinking formal economy in northern Nigeria is driving more educated people into the informal economy. That, in turn, pushes out the less educated, and leaves them more vulnerable to recruitment by Boko Haram and other violent groups and networks (Meagher 2014). Ibrahim Abdullah (1998) and Abubakar Momoh (2000) have pointed to the use of the vernacular term 'youthman', in many West African countries, which describes the large number of unemployed 35-year-olds, and older, struggling to attain social adulthood.

Young people — both men and women - feel excluded from what they perceive to be the good and prosperous modern life (Honwana \& De Boeck 2005). They want jobs, cell phones and tablets, jeans and fashionable clothing, cars, and the 'bling' they see paraded in hip-hop videos. A twenty-year old Mozambican from a remote village in Nampula said that he is trying to follow the advice of US rapper Fifty Cent "Get Rich or Die Tryin'."2 Many young people see waithood as stemming from national and global policies, that have failed to reduce poverty and to promote equitable and broadly distributed economic growth. Bad governance, corruption, and the absence of fundamental freedoms compound this predicament. Young people rebel against the widening gap between the rich and the poor, and the rampant corruption that they observe as elites enrich themselves at other people's expenses. But waithood also represents a period of political marginalization, which deprives young people of the space for political engagement, liberty of expression, and other civil liberties (Honwana 2012). They complain about political repression, social injustice, humiliation, and loss of dignity and freedom. 


\section{Waithood in the Developed World}

The concept of waithood can also be applied in the Western context, where in the past decades young people have increasingly struggled with their transition to adult life. As social psychologist Jeffrey Arnett (2004) has noted prolonged transitions to adulthood in the West, particularly among middle class youths in the USA, means that young people today stay in school longer, obtain their first paid jobs later, and start families much later than their twentiethcentury counterparts. Arnett calls this period 'emerging adulthood,' a new phase in the life course characterized by self-focused identity explorations, relative instability, and open possibilities. The expressions 'boomerang generation' and 'yo-yo generation' are used in the UK to depict young men and women who return home and continue to depend on their parents after graduating from college (Jones 1995). In Italy, for example, bamboccioni (big dummy boys) is an expression that mocks the growing number of unmarried young men in their mid-twenties and thirties who still live with their parents. In Japan, Freeters and the parasaito shinguru (parasite singles) refer to the growing number of young Japanese who are unable to participate in the labor market and begin their own families (Miyamoto 2002, 2004; Kosugi 2002, 2006). The social reality of increased unemployment, and its consequences, means that more and more young people in the West can no longer live according to the societal standards for material and social well-being. Researchers argue that this problem is tied to the declining effectiveness of socioeconomic and cultural processes in these affluent societies.

This situation is more difficult for young people from poor, working-class, and immigrant families in the developed world, who lack access to quality education, to prospects for regular employment, and to secure livelihoods. Racial, ethnic, and class disadvantages compound one another. African American youths in the United States are less likely to graduate from high 
school and go on to college than their white counterparts. Even with similar levels of education, they have far greater difficulty finding employment. Young black youth are trapped in a social environment of systemic failure (Fussell \& Furstenberg 2005). While African Americans make up only 13 percent of the population in the United States, there are markedly higher percentages of young black males who are incarcerated, charged with homicide, drop out of school, face unemployment, and live in poverty (Bonczar \& Beck 1997). The consequence of incarceration, for example, means that youth lose social and civic privileges and are blocked from job opportunities after release (Bosick \& Gover 2010). Moreover, excessive policing of black communities erodes their sense of belonging and reinforces their marginalization. Practices such as 'stop and frisk' simply exacerbate the level of surveillance, suspicion, and repression that young black men are already subjected to. "Every stop, every search, every arrest (...) every racist snub, every sexist remark, every homophobic joke..." (Murphy 2017:5) sends routine, authoritative signals about what society considers legitimate, and about whose status identity is to be affirmed or to be denied (Murphy 2017; McAra \& McVie 2010).

\section{Youth Movements and Social Change}

Unlike Bob Dylan's generation, today's generation is acutely conscious of their marginal structural position. Young people no longer trust the State's willingness and ability to find solutions to their problems. In their shared marginalization, they are developing a sense of common identity and a critical consciousness that lead them to challenge the established order. Like other social groups, youth have always been involved in everyday processes of social change, by fashioning the spaces within which they try to get by and assert their rights. Asef Bayat (2010) calls these dispersed actions 'non-movements,' which he describes as "quiet and 
unassuming daily struggles," outside formal institutional channels, in which ordinary activities blend with political activism. Young women and men engage in civil society associations, in popular culture, in debates through cyber social networks, and in political demonstrations. If we pay careful attention to the lyrics of their songs, the verses of their poems, the scripts of their plays, and to their discourses and images on Facebook, Instagram, Snapchat, WhatsApp, Tweeter, and Text Messages, we uncover a strong critique of the status quo.

Over the past few years, however, young people from all over the world have moved from a moderate encroachment on public space to an open and vociferous takeover of the national political stage. They have been questioning their waithood status and demanding better lives, declaring "Enough is Enough!” In Tunisia and Egypt, young people took to the streets to articulate grievances ranging from unemployment and corruption to the denial of free expression and civil liberties. Using slogans such as "Ben Ali Dégage” and "dignity and freedom not bread," the young protesters toppled the longstanding regimes of Ben Ali and Hosni Mubarak in 2011 (Honwana 2013). In Dakar, rallying around the movement Y'en a Marre! (We had Enough!), Senegalese youths voted massively to remove Abdoulaye Wade in the 2012 elections (Honwana 2012). Similarly, In Burkina Faso, in 2015, Le Balai Citoyen (The Citizen's Broom) led thousands of young Burkinabe in street demonstrations against the government, driving Blaise Campaore out after twenty-seven years in power (Harsch 2014; Engels, 2015).

In September 2015, South African university students protested across the country against fee increases that would hinder access to higher education for poor black students. The Fees Must Fall movement also called for the decolonization of the educational system and for transformation within universities to address racial and gender inequalities. What started as 
peaceful protest degenerated into violent confrontations between the students and the police (Langa 2017; Wessels, 2017).

In Spain, the protest movement Los Indignados (the Indignant) began in May 2011 and mobilized hundreds of thousands of young people. In several cities across the country, they took to the streets in a series of demonstrations, assemblies, and occupations of public spaces. They protested against the political and financial elites, whom they blamed for the country's severe economic crisis. They questioned the political system as a whole, demanding Democracia Real Ya! (Real Democracy Now!) (Martinez-Arboleda 2016).

In the United States, the Occupy Wall Street Movement rallied many young protesters against corporate greed and the corporations' undue influence over government. The movement protested the corrosive power of major banks and multinational corporations over the democratic process and their role in creating a major economic recession (Chandler 2014). Its focus on the nexus between state and corporate power and between public authority and private wealth created a common ground.

Born in 2013 as a Twitter hashtag, Black Lives Matter emerged after George Zimmerman's acquittal in the fatal shooting of the unarmed seventeen-year-old black youth Trayvon Martin. The movement was crystallized in 2014 when the hashtag leapt from social media into the streets during the Ferguson uprisings. Created by three strong female leaders, Black Lives Matter is galvanizing young people to fight against state-sanctioned violence. The movement sees social injustice in the United States as intrinsically connected to systemic racism and inequality, which in turn results in public school segregation and massive unemployment of black youth. Thus, the movement demands are broad based, including an end to mass 
incarcerations, greater investment in education, and employment opportunities for black youth (Cobb 2016).

Through an unprecedented show of unity, by taking to the streets and braving police, dictatorships have been overthrown, corrupt leaders voted out, unconstitutional presidential term extensions blocked, and governments forced to reverse unpopular decisions. In fact, from a vantage point outside dominant ideologies, younger generations have shown that they are capable of envisioning society and the polity anew, precisely because of what Karl Mannheim calls 'fresh contact,' a novel outlook that arises as the young assimilate, develop, and alter the social and cultural repository received from previous generations (Mannheim 1952).

\section{How to Effect Systemic Change?}

We have seen that young people have already effected significant changes. Their actions have expanded the political space for public participation and broadened the boundaries of individual freedoms, challenging the state's monopoly of the political discourse (Honwana 2012). In Tunisia, Senegal, and Burkina Faso, for example, populations once considered calm, docile, and intimidated have opposed the status quo with great courage and assertiveness. And in South Africa, the Fees Must Fall Movement has forced the government to institute some reforms and to increase funding for higher education. It also prompted curriculum transformation in some universities and the renaming of buildings still bearing colonial names (Langa 2017) At the same time, in the USA today, Black Lives Matter is influencing a national discourse about equality and citizenship by going beyond a critique of the justice system to a structural criticism of systemic racism. 
The achievements made by these youth movements so far can be credited to three main factors: First, the establishment of a new language. A priority of these movements was mobilization and the production of appealing slogans and short pieces of counter-hegemonic discourse. Words and expressions such as "Enough!," "Dégage," "1 percent versus 99 percent," "Fees must Fall," or "Real Democracy Now" embody simple and accessible messages that young people can relate to. The decentralized processes of production and consumption of language through online environments disrupts established conventions about authorship of the new language forms and enables them to be owned collectively (Martínez-Arboleda 2016). In this way, language has become a key attribute of the identity of these social movements, and not just a tool (Wessels 2017).

Second, the digital environment multiplied the messages and accelerated their distribution. Facebook, YouTube, Instagram, WhatsApp, and text messaging have been instrumental in energizing and mobilizing the masses through publicizing events (Nigam 2012). The use of such communication tools has, for example, led to the exposure of the abuses by corrupt regimes. The use of the Internet has facilitated cross-border exchanges in real time. Intensive use of social media has triggered and enabled significant changes, beyond the political struggles and dilemmas of earlier movements. Despite the dangers of misinformation, these autonomous online spaces facilitated the reframing of political issues, and of politics itself (Martínez- Arboleda 2016).

And third, Internet's social networks have facilitated horizontal communications and obviated the need for centralized organizations with strong hierarchical structures. The structures and modes of organization of these youth movements reflect a generation's deep disaffection with the political system. They have constituted themselves into organic voluntary associations 
of individual citizens, activists, bloggers, public communicators, grievances, local assemblies, and informal leadership networks. They strive to create new forms of political engagement, based on broad, decentralized, horizontal and consensus-based associations, imbued with strong anti-hierarchical and anti-authoritarian principles. As Melina Abdullah from Black Lives Matter pointed out, "There is a difference between being leaderless and being leaderful." 3 Indeed, these movements draw on group-centered leadership approaches.

Nevertheless, these movements have a long way to go toward broader systemic change. Once old regimes fall and the enthusiasm and energy of street protests wane, young activists find themselves more divided. The broad unity forged during street protests dissipates, as the youth struggle to articulate a new common purpose and to define a new political role for themselves (Honwana 2012, 2013). And, traditional and more established political forces quickly move in to occupy the institutional vacuum, often reverting to "politics as usual" with minor cosmetic changes. This could be seen, for example, in the tensions that emerged between leaders of the movements "Ça Suffit" and "Le Balai Citoyen" in Burkina Faso after the departure of Blaise Campaore. In Senegal, the "Yen a Marre" movement suffered from accusations that it received funding from Western countries. Tunisian and Egyptian activists struggled to negotiate new roles during the post-Ben Ali and the post-Mubarak transitions. Today, young Tunisians constitute the majority of Islamic State recruits, with about 6,000 fighting in Syria and Libya (Mishra 2015). The demise of Los Indignados and the Occupy Movement is attributed to the difficulty in sustaining momentum beyond the street protests. These factors expose the weaknesses of the large horizontal front in negotiating access to power within existing political conditions.

Young people have avoided the structures and political ideology that turn protest movements into political parties. They reject the established political order as corrupt and 
inadequate, but so far, they have been unable to produce an alternative political model. Reflecting on Los Indignados, sociologist Zygmunt Bauman observed that this is an emotional movement lacking forward thinking that could only prepare the ground for the construction, in the future, of a different type of organization ${ }^{4}$ (Verdu 2011). Actually, following the demise of the movement, in 2014, Pablo Iglesias, a young professor in his thirties, established Podemos (We Can!) as a formal political party. Podemos skillfully embedded the vision, linguistic strategies and contents of Los Indignados and made a careful use of social media, promising to honor the key demands of the youth movement. The poor showing of Podemos in the 2016 elections in Spain, and its subsequent alliance with the Spanish left — that created the 'Unidos Podemos' coalition — generated internal tensions and raised questions about the ability of a vertical party to represent a broader horizontal coalition such as Los Indignados (MartínezArboleda 2015). Youth movements continue to wrestle with identifying the appropriate structures and modes of organization for creating more sustainable political interventions that can shape public policies. There is a growing understanding among young activists that to effect systemic change, a broader and deeper approach is needed beyond national street protest. The question remains: can young people tackle the larger global system that still relegates them to the periphery of modernity?

\section{Challenging the Modernity Project?}

In Africa, confronting bad governance and corrupt leaders at home has led young activists to understand the limitations of effecting meaningful and far-reaching socioeconomic change in their countries. The neoliberal paradigm has hindered the ability of weak nations to attain socioeconomic sovereignty. As many analysts have pointed out, structural adjustment 
programs have seriously weakened the developing states' ability to determine national policies and priorities and to uphold the social contract with their citizenry. Indeed, neoliberalism diminished the role of the State, replacing public ownership with private enterprise and the withdrawal of the welfare programs. Development aid is often offered with strict conditions. And those in power in developing countries build close links with the wealthy and powerful in the Global North.

But this is not a novel problem. Already in the nineteenth century, Russian author and philosopher Fyodor Dostoevsky (1862) noted the weaknesses of the modern ideal of individual freedom for all, by identifying the gap between the theory and practice of liberal individualism. He considered this to be the very torment of modernity, in which individuals educated to believe in lofty notions of personal freedom and sovereignty ended up confronted with a reality that cruelly negated such dreams. Dostoevsky astutely noted that in France, as in other modern societies, the idea of liberté was a reality only for the wealthy and the powerful (Dostoevsky 1997; Mishra 2015). Today, neoliberalism continues to emphasize individualistic ideals, and expects citizens to become entrepreneurs able to repackage themselves to face a dynamically evolving capitalist economy. But capital continually moves globally, across national boundaries, in search of profit maximization, leaving behind and depriving millions of people. Defeat and humiliation have become commonplace experiences for many young people around the world, who are confronted with this global capitalist endeavor of profit making and franchising the individual self (Mishra 2015).

Even established liberal democracies such as the United States seethe with angry disillusionment across class and racial divides. Decades of liberal socioeconomic policies have led to a political system geared to facilitate private moneymaking. As the Occupy Movement put 
it: wealth is concentrated among one per cent of the population who dominate society, while ninety nine percent struggle. Bernie Sanders echoed this sentiment, when he stated that the issue of income and wealth inequality constituted the great moral, economic, and political issue of our time. Racial and ethnic discrimination is also at the center of this debate. In his book Between the World and Me, Ta-Nehisi Coates (2015) eloquently underscores the experience, and the struggles, of being young and black in America. The Black Lives Matter movement's fight against state-sanctioned violence, racial profiling, police brutality, mass incarceration, and lack of opportunities for black people embodies this struggle.

The situation is equally dire for the latecomers of modernity. Those from the periphery, for whom the gap between the notion of individual liberation and the daily experience of poverty and exclusion is even greater. The number of young people from Africa condemned to the 'waiting' room of modernity has grown significantly in recent decades. Young people's feelings of powerlessness and deprivation are exacerbated today by the ability, boosted by Internet and social media, to constantly compare their own lives with the lives of the fortunate and privileged. For many this contradiction has become intolerable. Young Africans are contesting their marginalization and trying to negotiate new terms of membership into the global community. Young people involved in movements such as Y'en a Marre in Senegal, Le Balai Citoyen in Burkina Faso, Filimbi (Whistles) and Lucha in the Democratic Republic of Congo, and Ça Suffit Comme ça in Gabon among others, are beginning to realize that united they will be stronger. They are working toward a Pan-African Coalition of Youth for Change, which includes links with young people in the African Diaspora in Europe and North America. These new youth movements are inspired by the anti-colonial resistance of an earlier generation, and cite Patrice Lumumba, Gandhi, Thomas Sankara, Fanon, Malcolm X and Nelson Mandela as some of their 
role models. In March 2015, when these movements met in Kinshasa, over forty activists were detained by the Congolese police on the grounds of inciting insurrection. Fadel Barro from Y'en a Marre, one of the detainees, pointed out that "they cannot imprison hope . . Y Youth will continue to mobilize" (Lewis \& Ross, 2015:2). A recent meeting of this Pan-African youth coalition was organized in Ouagadougou in October 2018 with the goal of creating a united strategy.

It is too early to know whether this generation will indeed be able to achieve far-reaching systemic change. What is clear is the emergence of a strong personal and collective realization that they can be a force for change. It means that this waithood generation that may seem to be doomed to lurch between a sense of inadequacy, despondency, and lack of fulfillment, is courageously challenging the establishment. Radical and systemic change will take time. It will require more organization, more structure, and a new kind of politics. It might even take more than a generation, but I believe that young people in waithood have already started the process. And this, maybe, is where we can find hope for the future of the world. 


\section{References}

Abdullah, Ibrahim. 1998. "Bush Path to Destruction: The origin and Character of the Revolutionary United Front/Sierra Leone.” Journal of Modern African Studies 36(2): $203-34$.

Arnett, Jeffrey. 2004. Emerging adulthood: The winding road from the late teens through the twenties. Oxford: Oxford University Press.

Bayat, Asef. 2010. Life as Politics: How Ordinary People Change the Middle East. Stanford: Stanford University Press.

Bonczar, Thomas, and Allen Beck. 1997. "Lifetime Likelihood of Going to State or Federal Prison.” Bureau of Justice Statistics Bulletin, NCJ 1600092. Washington DC: United States Department of Justice.

Bosick, Stacey, and Angela Gover. 2010. "Incarceration during the Transition to Adulthood: a 'snapshot' of at-risk males at twenty-five." American Journal of Criminal Justice 35(3):93-104.

Chandler, Jahaan. 2014. "Social Theory and the Occupy Movement: An Exploration into the Relationship between Social Thought and Political Practice.” M.A. diss., University of New Orleans.

Coates, Ta-Nehisi. 2015. Between the World and Me. New York: Spiegel \& Grau, Penguin Random House.

Cobb, Jelani. 2016. "The Matter of Black Lives: A new kind of movement found its moment. What will its future be?" The New Yorker, March 14. 
De Certeau, Michel. 1984. The Practice of Everyday Life. Translated by Steven Rendall.

Berkeley: University of California Press.

Dostoevsky, Fyodor. 1997. Winter Notes on Summer Impressions (1862). Translated by David

Patterson. Evanston: Northwestern University Press.

Engels, Bettina. 2015. "Political Transition in Burkina Faso: The Fall of Blaise Compaoré." Governance in Africa, 2 (1): 1-6.

Fussell, Elizabeth, and Frank Furstenberg Jr. 2005. "The Transition to Adulthood during the 20th Century: Race, Nativity, and Gender." In On the Frontier of Adulthood: Theory, Research and Public Policy, edited by Richard Settersten Jr., Frank Furstenberg Jr., and Rubén Rumbaut, 29-75. Chicago: University of Chicago Press.

Harsch, Ernest. 2014. "Citizens' Revolt in Burkina Faso”. African Futures. Social Science Research Council, New York. December. Available online at: http://forums.ssrc.org/african-futures/2014/12/09/citizens-revolt-in-burkina-faso/

Honwana, Alcinda. 2013. Youth and Revolution in Tunisia. London: Zed Books.

— 2012. The Time of Youth: Work, Social Change and Politics in Africa. Sterling, VA: Kumarian Press, Lynne Rienner.

Honwana, Alcinda, and Filip De Boeck, eds. 2005. Makers and Breakers: Children and Youth in Postcolonial Africa. Oxford: James Currey; Trenton, NJ: Africa World Press; Dakar: Codesria.

Jones, Gill. 1995. Leaving Home. Buckingham: Open University Press

Kosugi, Reiko. 2002. "The transition from school to work in recent Japan: The experiences of freeters." Journal of Educational Sociology 70, 59-74. 
- 2006. Changes in transitions from school to work: Employment behavior and transitions

of youth in metropolitan areas. Japan Institute for Labour Policy and Training (JILPT) Research Report 72.

Langa, Malose, ed. 2017. “\#Hashtag: An Analysis of the \#FeesMustFall Movement at South African Universities." Centre for the Study of Violence and Reconciliation. Johannesburg.

Lewis, David, and Aaron Ross, 2015. "Connected and Angry, African Youth Groups Push for Democracy." Reuters Special Reports. May. Available online at: https://www.reuters.com/article/uk-africa-democracy-insight/insight-connected-andangry-african-youth-groups-push-for-democracy-idUKKBN0NM3VI20150501

Lévi-Strauss, Claude. 1966. The Savage Mind. Chicago: University of Chicago Press.

Mannheim, Karl. 1952 (1927). “The problem of generations." In Essays on the Sociology of knowledge, edited by Paul Kecskemeti. London: Routledge.

Martínez-Arboleda, Antonio. 2016. "Podemos and the 15M Language Community." New Politics. 60 (4): 99-107.

—. 2015. "Podemos, the 15M Indignados Movement and the Radical Left in Spain." New Politics. 17 December. Available online at: http://newpol.org/content/podemos-15mindignados-movement-and-radical-left-spain

McAra, Lesley, and Susan McVie. 2010. "Youth Crime and Justice: Key messages from the Edinburgh Study of Youth.” Criminology and Criminal Justice 10 (2):179-209.

Meagher, Kate. 2014. "Disempowerment from Below: Informal Enterprise Networks and the Limits of Political Voice in Nigeria." Oxford Development Studies, 42 (3): 419-38. 
Miyamoto, Michiko. 2002. Wakamono ga Shakaiteki Jyakusha ni Tenraku Suru (The emergence of youth as a socially disadvantaged class). Tokyo: Yōsensha.

—_. 2004. Shakaiteki haijo to jyakunen mugyō: Igirisu to Suēden no taiō (Social exclusion and youth uemployment: The responses of the UK and Sweden). Nihon Rōdo Kenkyū Zasshi. 53 (3): 17-26

Mishra, Pankaj. 2015. "How to think about Islamic State.” The Guardian. Available online at: https://www.theguardian.com/books/2015/jul/24/how-to-think-about-islamic-state

Momoh, Abubakar. 2000. "Youth culture and area boys in Lagos." In Identity transformation and identity politics under structural adjustment in Nigeria, edited by Attahiru Jega, 181203. Stockholm: Nordic Africa Institute.

Moore, Henrietta. 2011. Still Life: hopes, desires and satisfaction. Cambridge: Polity Press.

Murphy, Sean. 2017. "The Policing of Belonging: Youth, Marginalization and 'Stop and Search'." Youth Think, 13 June. Available online at: https://youththink.wordpress.com/2017/06/13/the-policing-of-belonging-youthmarginalisation-and-stop-and-search/

Nigam, Aditya. 2012. "The Arab Upsurge and the Viral Revolutions of our Times." Interface 4 (1): $165-77$.

Wessels, Nastassja. 2017. “\#FeesMustFall: Discourse Hidden in Plain Sight.” MA diss., Tilburg University, The Netherlands.

Verdu, Vicente. 2011. “El 15-M es emocional, le falta pensamiento.” El País, October 17, 2011. Available online at: https://elpais.com/diario/2011/10/17/cultura/1318802401_850215.html 
Vigh, Henrik. 2009. "Youth Mobilization as Social Navigation: Reflections on the Concept of "5ubriagem'." Cadernos de Estudos Africanos 18/19: 140-64, Instituto Universitário de Lisboa (ISCTE).

\section{Endnotes}

\footnotetext{
${ }^{1}$ Lyrics from the "Times They Are a-Changing" a song first played by Bob Dylan in October 1963.

${ }^{2}$ The title of Fifty Cent's debut album released in February 2003.

${ }^{3}$ Melina Abdullah in interview with Tavis Smiley, November 2016

4 Zygmunt Bauman in an interview with Vicente Verdu, El País, in Madrid in 2011.
} 